\title{
A Functional Tph2 Cl473G Polymorphism Causes an Anxiety Phenotype via Compensatory Changes in the Serotonergic System
}

\author{
Stefan M Berger ${ }^{1,9}$, Tillmann Weber ${ }^{1,2,3,9}$, Stephanie Perreau-Lenz ${ }^{4}$, Miriam A Vogt ${ }^{5}$, Sarah E Gartside ${ }^{6}$, \\ Christiane Maser-Gluth ${ }^{7}$, Laurence Lanfumey ${ }^{8}$, Peter Gass ${ }^{5}$, Rainer Spanagel ${ }^{4}$ and Dusan Bartsch*, \\ 'Department of Molecular Biology, Central Institute of Mental Health, Medical Faculty Mannheim/Heidelberg University, Mannheim, Germany; \\ ${ }^{2}$ Department of Addictive Behavior and Addiction Medicine, Central Institute of Mental Health, Medical Faculty Mannheim/Heidelberg \\ University, Mannheim, Germany; ${ }^{3}$ Department of Psychiatry and Psychotherapy, Central Institute of Mental Health, Medical Faculty Mannheim/ \\ Heidelberg University, Mannheim, Germany; ${ }^{4}$ Institute of Psychopharmacology, Central Institute of Mental Health, Medical Faculty Mannheim/ \\ Heidelberg University, Mannheim, Germany; ${ }^{5}$ Department of Psychiatry and Psychotherapy, Research Group Animal Models in Psychiatry, \\ Central Institute of Mental Health, Medical Faculty Mannheim/Heidelberg University, Mannheim, Germany; ${ }^{6}$ Institute of Neuroscience,

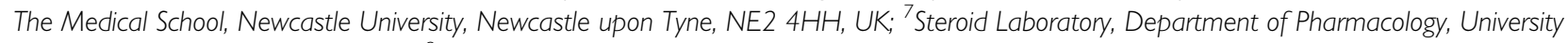 \\ of Heidelberg, Heidelberg, Germany; ${ }^{8}$ INSERM UMRS894, CPN, Université Pierre and Marie Curie, Paris, France
}

\begin{abstract}
The association of single-nucleotide polymorphisms (SNPs) in the human tryptophan hydroxylase 2 (TPH2) gene with anxiety traits and depression has been inconclusive. Observed inconsistencies might result from the fact that TPH2 polymorphisms have been studied in a genetically heterogeneous human population. A defined genetic background, control over environmental factors, and the ability to analyze the molecular and neurochemical consequences of introduced genetic alterations constitute major advantages of investigating SNPs in inbred laboratory mouse strains. To investigate the behavioral and neurochemical consequences of a functional CI473G SNP in the mouse Tph2 gene, we generated congenic C57BL/6N mice homozygous for the Tph2 I473G allele. The Arg ${ }^{447}$ substitution in the $\mathrm{TPH} 2$ enzyme resulted in a significant reduction of the brain serotonin (5-HT) in vivo synthesis rate. Despite decreased 5-HT synthesis, we could detect neither a reduction of brain region-specific 5-HT concentrations nor changes in baseline and stress-induced 5-HT release using a microdialysis approach. However, using a $\left[{ }^{35} \mathrm{~S}\right] \mathrm{GTP}-\gamma-\mathrm{S}$ binding assay and $5-\mathrm{HT}_{\text {IA }}$ receptor autoradiography, a functional desensitization of 5-HTIA autoreceptors could be identified. Furthermore, behavioral analysis revealed a distinct anxiety phenotype in homozygous Tph2 1473G mice, which could be reversed with chronic escitalopram treatment. Alterations in depressive-like behavior could not be detected under baseline conditions or after chronic mild stress. These findings provide evidence for an involvement of functional Tph2 polymorphisms in anxiety-related behaviors, which are likely not caused directly by alterations in 5-HT content or release but are rather due to compensatory changes during development involving functional desensitization of 5-HTIA autoreceptors. Neuropsychopharmacology (2012) 37, 1986-1998; doi:10.1038/npp.2012.46; published online II April 2012
\end{abstract}

Keywords: TPH2; serotonin; anxiety; depression; 5-HTIA receptor; SSRI

\section{INTRODUCTION}

Dysfunction within central serotonergic neurotransmission is regarded as a major factor implicated in many neuropsychiatric diseases, such as anxiety and depressive disorders (Ressler and Nemeroff, 2000). Standard therapy

*Correspondence: Professor Dr D Bartsch, Department of Molecular Biology, Central Institute of Mental Health, Medical Faculty Mannheim/ Heidelberg University, J-5, 68159 Mannheim, Germany, Tel: + 49621 1703 6202, Fax: + 496211703 6205,

E-mail: dusan.bartsch@zi-mannheim.de

${ }^{9}$ These authors contributed equally.

Received 6 October 2011; revised 28 February 2012; accepted 14 March 2012 for these disorders involves substances targeting the serotonergic system (Blier and de Montigny, 1999) and association studies have linked single-nucleotide polymorphisms (SNPs) in genes modulating serotonergic neurotransmission with these disorders (Anguelova et al, 2003; Murphy and Lesch, 2008; Yu et al, 2005).

Since the discovery of the tryptophan hydroxylase 2 (TPH2) isoenzyme (Walther et al, 2003) - the rate-limiting enzyme of 5-HT synthesis in the brain - TPH2 polymorphisms in humans have been associated with anxiety traits, depressive disorders, and suicidality (Gutknecht et al, 2007; Reuter et al, 2007; Van Den Bogaert et al, 2006; Zhang et al, 2005; Zill et al, 2004a, b) yet these results have not been supported by other studies (De Luca et al, 2006; Garriock 
et al, 2005; Juhasz et al, 2010; Lopez et al, 2007; Mann et al, 2008; Middeldorp et al, 2010). These discrepancies might be partially attributed to the fact that different SNPs in the TPH2 gene were analyzed. Most of the reported polymorphisms have not been characterized regarding their functional consequences on TPH2 transcription or 5-HT synthesis in vivo. Also, environmental factors like stress or genetic diversity are confounding variables that need to be taken into account in human studies.

In studies with rodents, control over environmental factors and a defined genetic background constitute major advantages for investigating the contribution of single-nucleotide alterations on the organism. For the mouse Tph2 gene, a functional SNP has been identified (C1473G) among different inbred mouse strains, which results in the substitution of Pro ${ }^{447}$ (1473C allele) with $\operatorname{Arg}^{447}$ (1473G allele). In mouse strains homozygous for the $1473 \mathrm{G}$ allele $(\mathrm{G} / \mathrm{G})$, the enzymatic activity of TPH2 was reduced by $50 \%$ and correspondingly 5 -HT concentrations were found to be decreased in several brain regions (Zhang et al, 2004). Inconsistent results were reported in subsequent studies, which tried to correlate the Tph2 C1473G polymorphism with behavioral differences in mouse strains homozygous for either the $\mathrm{G} / \mathrm{G}$ allele (DBA/2 and BALB/c) or C/C allele (C57BL/6 and 129) (Cervo et al, 2005; Crowley et al, 2005). However, the divergent genetic background among different inbred mouse strains may have contributed to the inconsistencies found in the behavioral analysis of the Tph2 C1473G SNP.

The strategy of choice to investigate the impact of single gene modifications on complex physiological and behavioral traits is the introduction of a particular genetic variation into the genome of an animal with a suitable inbred genetic background. With this approach, a comparative functional analysis of a specific SNP on an identical genetic background is feasible. This can either be achieved by a knock-in strategy in embryonic stem cells (Beaulieu et al, 2008) or alternatively by generating congenic strains by a backcrossing strategy in which one inbred strain is mated to another recipient inbred strain (Tenner et al, 2008). A 'knock-in' approach was applied to study the consequences of the human TPH2 SNP G1463A (Beaulieu et al, 2008), which previously had been shown to be associated with unipolar depressive disorder (Zhang et al, 2005). The respective polymorphism (G1449A) in the mouse Tph2 gene reduced the enzymatic activity of TPH 2 by $80 \%$ and led to a highly significant reduction of extracellular 5-HT concentration in several brain regions (Jacobsen et al, 2011). This correlated with an increase in anxiety- and depressionrelated behavior. In contrast, congenic C57BL/6 mice homozygous for the $1473 \mathrm{G}$ - generated by a backcrossing strategy - showed no differences in either brain stem TPH2 activity in vitro or brain region-specific 5-HT concentrations compared with littermates homozygous for the $1473 \mathrm{C}$ allele (Tenner et al, 2008). Also, anxiety and depressive-like behavior were undistinguishable between respective mice.

Here, we provide a detailed comparative neurochemical, molecular, and behavioral characterization of $\mathrm{C} 57 \mathrm{BL} / 6 \mathrm{~N}$ mice homozygous for either the Tph2 $1473 \mathrm{G}$ or $1473 \mathrm{C}$ allele. On an otherwise identical genetic background, we show that the Tph $21473 \mathrm{G} / \mathrm{G}$ allele alone leads to a reduced in vivo 5-HT synthesis rate. However, the distinct and pharmacologically reversible anxiety phenotype in $1473 \mathrm{G} / \mathrm{G}$ mice is not the result of reduced 5-HT tissue content or 5-HT neurotransmission but is likely mediated via compensatory homeostatic changes involving a functional desensitization of $5-\mathrm{HT}_{1 \mathrm{~A}}$-autoreceptors.

\section{MATERIALS AND METHODS}

\section{Animals}

Congenic C57BL/6N animals, homozygous for the Tph2 $1473 \mathrm{G}$ allele (1473G/G mice), were generated using a backcrossing breeding strategy. DBA/ $2 \mathrm{~N}$ inbred mice, which are homozygous for the $1473 \mathrm{G}$ allele, were backcrossed to a C57BL/6N genetic background for 10 generations. Congenic C1473G C57BL/6N mice were then bred to homozygosity. Inbred C57BL/6N mice, homozygous for the Tph2 $1473 \mathrm{C}$ allele (1473C/C mice) were purchased from Charles Rivers Laboratories (Sulzfeld, Germany). Breedings and litter sizes of $1473 \mathrm{G} / \mathrm{G}$ mice were normal and genotypes followed Mendelian distribution. For genotyping of the Tph2 1473G and $1473 \mathrm{C}$ allele and housing condition of the animals, see Supplementary section for details.

\section{Neurochemistry}

The whole brain from experimentally naive male $1473 \mathrm{C} / \mathrm{C}$ and 1473 G/G mice was cut sagitally and each brain hemisphere was manually microdissected into a forebrain section (containing projections of serotonergic neurons) and a midbrain/brainstem section (containing the cell bodies of serotonergic neurons from median and dorsal raphe nuclei (DRN)). For the determination of the synthesis rate of TPH2, mice were injected with the L-aromatic acid decarboxylase inhibitor NSD 1015 ( $m$-hydroxybenzyl-hydrazine; $100 \mathrm{mg} / \mathrm{kg}$ i.p.) $30 \mathrm{~min}$ before brain dissection. Dissected brain regions were homogenized in an extraction solution (0.1 M perchloric acid, $1 \mathrm{mM}$ EDTA) using a tissue homogenizer Mixer Mill (Qiagen, Hilden, Germany) and yielded solutions subsequently centrifuged at $15000 \mathrm{~g}$ for $10 \mathrm{~min}$ at $4{ }^{\circ} \mathrm{C}$. In all, $10 \mu \mathrm{l}$ of the spun sample was loaded on a HPLC system with electrochemical detection (see Supplementary section for details). Brain regionspecific accumulation of 5-hydroxytryptophan (5-HTP) and L-DOPA - serotonin and dopamine precursor molecules-or of 5-HT and 5-HIAA tissue concentration was determined by normalizing the quantified neurotransmitter amounts to the respective weight of the tissue sample.

\section{Microdialysis}

Three-month old, experimentally naive male $1473 \mathrm{C} / \mathrm{C}$ and $1473 \mathrm{G} / \mathrm{G}$ mice were used. Surgical procedures, sampling of microdialysates, and quantification of extracellular 5-HT was performed as previously described (Engblom et al, 2008) (see Supplementary section for details).

\section{Quantitative Autoradiography of $5-\mathrm{HT}_{1 \mathrm{~A}}$-Mediated $\left[{ }^{35} \mathrm{~S}\right] \mathrm{GTP}-\gamma-\mathrm{S}$ Binding and $\left[{ }^{3} \mathrm{H}\right]-\mathrm{WAY} 100635$ Binding}

Six-month old, experimentally naive male $1473 \mathrm{C} / \mathrm{C}$ and 1473 G/G mice were used for autoradiographic measurements of 
$5-\mathrm{HT}_{1 \mathrm{~A}}$ receptor-stimulated $\left[{ }^{35} \mathrm{~S}\right] \mathrm{GTP}-\gamma-\mathrm{S}$ binding in the DRN and the CA1 area of the hippocampus as previously described (Froger et al, 2004). In a separate group of 3month old, experimentally naive male mice of both Tph2 genotypes, $\left[{ }^{3} \mathrm{H}\right]$-WAY100635 binding was performed on sections containing the DRN as previously described (Khawaja, 1995) (see Supplementary section for details).

\section{Plasma Corticosterone Concentrations}

Blood was collected from the saphenous vein according to Hoff (2000) using an EDTA-coated Microvette CB300 (Sarstedt, Nürnbrecht, Germany) and yielded serum was stored at $-20^{\circ} \mathrm{C}$. Corticosterone was quantified by a specific in-house radioimmunoassay (RIA) established at the Steroid Laboratory of the Department of Pharmacology, University of Heidelberg as previously described (Bielohuby et al, 2007). A recovery-corrected extraction was performed before each RIA. Intra-assay and inter-assay coefficients of variance were $<10 \%$ and $<15 \%$, respectively.

\section{Behavioral Analysis}

The animal numbers and the order of the behavioral experiments are displayed in Supplementary Table S1. The experimental protocols used in this study complied with national and international ethical guidelines, and were performed in compliance with the German Animal Welfare Act and approved by the Animal Welfare Commission of the Regierungspräsidium Karlsruhe, Germany (35-9185.81/ G-182/09). All experiments were conducted only with male mice during the 'dark' period of the day, that is, in the animals' active phase. Experimental procedures of the open field test and hotplate test are described in the Supplementary section.

\section{Elevated Plus Maze}

The elevated plus maze is a widely used test to determine the state anxiety of an animal. The apparatus (see Supplementary section for details) consisting of two open and two enclosed arms was illuminated indirectly by an overhead lamp with an intensity of 25 lux. For testing, mice were individually placed on the center square facing an enclosed arm, and allowed to freely explore the maze for $5 \mathrm{~min}$. Their behavior was recorded and analyzed by the video tracking software EthoVision 3.0 (Noldus, Wageningen, The Netherlands). Parameters assessed were time spent in open or closed arms, number of exits into the open arms, number of head dips, number of transitions between arms and total distance moved.

\section{Elevated Zero-Maze}

The elevated zero-maze inflicts an approach-avoidance conflict on the mice, measuring anxiety by their aversion to enter the elevated, exposed sections of a round maze. The experiment was performed as previously described (Fuss et al, 2010). The following parameters were analyzed: latency to first exit, number of exits to, and total time spent in the open compartments.

\section{Light-Dark Exploration Test}

The light-dark exploration test examines the anxietyrelated behavior to an aversively, brightly lit compartment. The test apparatus ('dark-light box') consisted of two plastic chambers, connected by a tunnel of $5 \times 7 \times 10 \mathrm{~cm}$ $(\mathrm{l} \times \mathrm{w} \times \mathrm{h})$. The 'dark' chamber (black plastic) measured $20 \times 15 \times 30 \mathrm{~cm}(1 \times \mathrm{w} \times \mathrm{h})$ and was covered by a lid. The lit chamber, $30 \times 15 \times 30 \mathrm{~cm}(1 \times \mathrm{w} \times \mathrm{h})$, made of white plastic, was brightly illuminated from above with tubular fluorescent lamps (1000 lux). Mice were individually placed into the dark compartment and their behavior was monitored by the video tracking software EthoVision 3.0 (Noldus) for $5 \mathrm{~min}$. Analyzed parameters included: latency of first exit and number of exits into the lit compartment, time and distance moved in the lit compartment, risk assessments (head dips from the dark compartment), and time of endexploration.

\section{Novelty-Induced Hypophagia}

The novelty-induced hypophagia test is an animal model for anxiety-related behavior, which is sensitive to chronic but not acute treatment of the animal with serotonin reuptake inhibitors (Dulawa and Hen, 2005). Mice are first trained to consume sweetened condensed milk (1:3 dilution of La Lechera (Nestlé, Frankfurt, Germany) with water) in their home cage once a day for $1 \mathrm{~h}$. A trained observer scored the mice for their latency to start consuming milk and for their consumption of milk within the first $10 \mathrm{~min}$ and the whole training session (60 min). Training was continued until the latency to start consuming milk was below $20 \mathrm{~s}$. Mice that never consumed milk during home cage testing (1473C/C: $n=1)$ were eliminated from the experiment. The next day following training, the sweetened condensed milk was presented to each individual mouse within a novel environment (new cage without bedding or a new cage with a metal floor) for $10 \mathrm{~min}$ and the applicable parameters were scored by the observer. For escitalopram treatment, see Supplementary section for details.

\section{Tail Suspension Test}

The tail suspension test determines despair behavior (failure in the persistence of escape-directed behavior toward a stressor) of the animal. Here, mice were individually suspended by their tail taped to a metal hook connected to a strain gauge, which is part of a computerassisted tail suspension test device (Bioseb, Chaville, France). Within the $5 \mathrm{~min}$ of testing, all movements of the mice were automatically recorded. The parameter of the test is the total duration of immobility.

\section{Forced Swimming Test}

To quantify depression-related despair behavior, mice were placed into a glass cylinder $(23 \mathrm{~cm}$ height, $13 \mathrm{~cm}$ diameter $)$, which was filled with water $\left(22^{\circ} \mathrm{C}\right)$ up to a height of $10 \mathrm{~cm}$. Within the testing period of $6 \mathrm{~min}$, the activity of each mouse was recorded from the side by the video tracking software EthoVision 3.0 (Noldus). Immobility was defined 
as motionless floating in water, only allowing movements necessary for the animal to keep its head above the water.

\section{Learned Helplessness}

The learned helplessness paradigm is a depression model in which an animal is exposed to unpredictable and uncontrollable stressors. This subsequently leads to the development of coping deficits in aversive but escapable situations. The experimental procedure was used as previously described (Chourbaji et al, 2005) (see Supplementary section for details).

\section{Chronic Mild Stress Procedure}

Chronic mild stress applied to rodents is considered as an etiological model of depression (Willner, 1997). The procedure applied herein was performed as described by Pothion et al (2004) with some modifications (see Supplementary section for details).

\section{Sucrose Preference Using a 'Matching Law' Approach}

Anhedonia, the loss of interest in pleasurable activities, is a core symptom of depressive disorders (APA, 2000). To detect hedonic alterations in rodents, the reinforcing properties of sucrose were assessed by a free choice, two-bottle sucrose consumption paradigm using the principles of the matching law, which provides a quantitative index of the steady, internal evaluation of the reward (Herrnstein, 1961). The testing procedure used herein was adapted from SanchisSegura et al (2004) (see Supplementary section and Supplementary Table 2 for details).

\section{Statistical Analysis}

Statistical analyses were performed using either $t$-test or univariate or multivariate analysis of variance (ANOVA) with repeated or independent measures (factors included: genotype, stress, cage environment, and time), followed by either a Bonferroni or Dunnett post hoc test. Respective F- and $p$-values were calculated using GraphPad Prism 5.0 or SPSS Version 19. All data are presented as either mean + SEM or mean \pm SEM. $p<0.05$ was considered statistically significant.

\section{RESULTS}

\section{In vivo 5-HT Synthesis Rate in Homozygous Tph2 1473G Mice}

We first analyzed the in vivo 5 -HT synthesis rate in mice homozygous for either the $1473 \mathrm{G}$ or $1473 \mathrm{C}$ allele. After injection of the L-aromatic amino-acid decarboxylase inhibitor NSD 1015, the accumulation of the 5-HT precursor 5-HTP and the dopamine precursor L-DOPA was quantified in both the 5-HT neuronal projection areas in the forebrain and in the midbrain/brain stem where 5-HT neurons reside in the raphe nuclei (Table 1). As expected, the dopamine synthesis rate, reflected by accumulation of L-DOPA, was unaffected by the C1473G SNP. In contrast, mice homozygous for the $1473 \mathrm{G}$ allele showed a highly significant $30 \%$ reduction of total brain 5-HT synthesis relative to $1473 \mathrm{C} / \mathrm{C}$ mice. There were brain regional differences with forebrain 5-HTP accumulation significantly reduced by $40 \%$ whereas 5-HT synthesis rate in the raphe nuclei of midbrain/brain stem punches showed only a small and nonsignificant decrease.

\section{5-HT Concentration, Metabolism, and Synaptic Release in Homozygous Tph2 1473G Mice}

We next analyzed the impact of reduced 5-HT synthesis on brain 5-HT concentration and metabolism. Tissue concentrations of 5-HT and 5-HIAA were determined from forebrain and midbrain/brain stem sections by HPLC with electrochemical detection.

Despite a significant reduction of in vivo 5 -HT synthesis, there was no concomitant reduction in tissue 5-HT. Thus, forebrain 5-HT tissue concentration in 1473G/G mice was undistinguishable from homozygous $1473 \mathrm{C} / \mathrm{C}$ mice (Table 2), while in midbrain/brain stem samples, there was a small $15 \%$ increase in $5-\mathrm{HT}$ concentration in $1473 \mathrm{G} / \mathrm{G}$ mice relative to $1473 \mathrm{C} / \mathrm{C}$ mice. When total brain $5-\mathrm{HT}$ concentration was calculated, no significant differences were detected in mice of both Tph2 alleles.

Compensation for reduced 5-HT synthesis could occur via decreased 5-HT metabolism. Indeed, the 5-HIAA concentration in the forebrain of $1473 \mathrm{G} / \mathrm{G}$ mice was significantly $15 \%$ lower than in $1473 \mathrm{C} / \mathrm{C}$ mice (Table 2). This resulted in a significant reduction of the 5-HT turnover rate (5-HIAA/5HT ratio; Table 2) in the forebrain. In contrast, within the

Table I Serotonin and Dopamine Synthesis Rate in Homozygous I473G and I473C Mice

\begin{tabular}{|c|c|c|}
\hline & DOPA & 5-HTP \\
\hline \multicolumn{3}{|l|}{ Forebrain } \\
\hline I473C/C & $1.30 \pm 0.26$ & $0.79 \pm 0.04$ \\
\hline | 473G/G & $1.26 \pm 0.25$ & $0.48 \pm 0.02 * * * *$ \\
\hline \multicolumn{3}{|c|}{ Midbrain/brain stem } \\
\hline I473C/C & $0.78 \pm 0.16$ & $1.45 \pm 0.07$ \\
\hline |473G/G & $0.94 \pm 0.17$ & $1.27 \pm 0.09$ \\
\hline \multicolumn{3}{|l|}{ Total } \\
\hline I473C/C & $1.18 \pm 0.24$ & $0.94 \pm 0.04$ \\
\hline |473G/G & $1.19 \pm 0.23$ & $0.64 \pm 0.03$ ***** \\
\hline
\end{tabular}

Brain tissue concentrations of 5-hydroxytryptophan (5-HTP; serotonin precursor) and dihydroxyphenylalanin (DOPA; dopamine precursor) were determined in experimentally naive male I473G/G $(n=5)$ and I 473C/C mice $(n=5)$ that had been treated with the L-aromatic amino acid decarboxylase inhibitor NSD 1015 $30 \mathrm{~min}$ before analysis. Concentrations of accumulated DOPA, representing dopamine synthesis, were undistinguishable between homozygous mice of both Tph2 alleles. Accumulated 5-HTP concentrations representing 5-HT synthesis were significantly lower by $40 \%$ in the forebrain $(p<0.00 \mathrm{I})$ and insignificantly lower by $15 \%$ in the midbrain/brain stem of $1473 \mathrm{G} / \mathrm{G}$ mice. The total $5-\mathrm{HTP}$ brain content was significantly reduced by $30 \%(p<0.00 \mathrm{I})$. All data are presented as mean values \pm SEM. All stars represent $p$-values of significances between genotypes from unpaired $t$-tests.

**** $p<0.001$ 
Table 2 5-HT and 5-HIAA Tissue Concentrations in Homozygous |473G/G and I473C/C Mice

\begin{tabular}{|c|c|c|c|}
\hline & 5-HT & 5-HIAA & 5-HIAA/5-HT \\
\hline \multicolumn{4}{|l|}{ Forebrain } \\
\hline I473C/C & $3.98 \pm 0.18$ & $1.12 \pm 0.06$ & $0.282 \pm 0.010$ \\
\hline I473G/G & $3.89 \pm 0.10$ & $0.95 \pm 0.03 *$ & $0.246 \pm 0.009 *$ \\
\hline \multicolumn{4}{|c|}{ Midbrain/brain stem } \\
\hline I473C/C & $5.11 \pm 0.10$ & $2.29 \pm 0.10$ & $0.449 \pm 0.019$ \\
\hline 1473G/G & $5.76 \pm 0.23 *$ & $2.44 \pm 0.09$ & $0.425 \pm 0.013$ \\
\hline \multicolumn{4}{|l|}{ Total } \\
\hline I473C/C & $4.24 \pm 0.13$ & $1.38 \pm 0.07$ & $0.327 \pm 0.012$ \\
\hline |473G/G & $4.28 \pm 0.10$ & $1.27 \pm 0.04$ & $0.297 \pm 0.011$ \\
\hline
\end{tabular}

Tissue concentrations of 5-HT and 5-HIAA were determined in the forebrain and midbrain/brain stem of experimentally naive male I473G/G $(n=7)$ and $1473 \mathrm{C} / \mathrm{C}$ mice $(n=8)$. 5-HT turnover $(5-\mathrm{HIAA} / 5-\mathrm{HT})$, representing metabolism rate, was calculated from the measured concentrations. In the forebrain, 5-HT concentrations were similar in homozygous mice of both Tph2 alleles but 5-HIAA concentration $(p=0.032)$ and 5-HT turnover $(p=0.022)$ were significantly reduced by $15 \%$ in $1473 \mathrm{G} / \mathrm{G}$ mice. In the midbrain/brain stem, I473G/G mice showed a significantly elevated 5-HT concentration by $13 \%(p=0.020)$. However, 5-HIAA and turnover rate were similar between homozygous Tph2 I473G and I473C mice in this brain region. For the total brain, 5-HT and 5-HIAA concentrations were similar in both groups. All data is presented as mean values \pm SEM. All symbols represent $p$-values of significances between genotypes from unpaired $t$-tests.

$* p<0.05$. midbrain/brain stem section no difference in 5-HIAA concentrations or 5-HT turnover rate could be detected between $1473 \mathrm{G} / \mathrm{G}$ and $1473 \mathrm{C} / \mathrm{C}$ mice.

As no major alterations in brain 5-HT content could be identified, we next determined the impact of reduced 5-HT synthesis on basal and stress-induced 5-HT release. Microdialysis in freely moving animals was performed in the ventral hippocampus and the prefrontal cortex, two brain regions innervated by serotonergic projections originating from dorsal and median raphe nuclei (Azmitia and Segal, 1978). Microdialysis samples were taken every $20 \mathrm{~min}$, first under basal conditions for $100 \mathrm{~min}$, thereafter during restraint stress for $1 \mathrm{~h}$ and finally after termination of stress (post-stress) for $1 \mathrm{~h}$. Basal extracellular 5-HT concentrations were indistinguishable between the $\mathrm{G} / \mathrm{G}$ and $\mathrm{C} / \mathrm{C}$ mice in the prefrontal cortex (Figure 1b) as well as in the ventral hippocampus (Figure 1d). Furthermore, both the stressinduced increase in extracellular 5-HT and the persistence of elevated post-stress 5-HT concentrations were not significantly different in homozygous $1473 \mathrm{C}$ and $1473 \mathrm{G}$ mice in either brain region investigated (Figures $1 \mathrm{a}$ and $\mathrm{c}$ ).

\section{Functional Desensitization of 5- $\mathrm{HT}_{1 \mathrm{~A}}$ Autoreceptors in the DRN of Homozygous Tph2 1473G Mice}

Despite reduced 5-HT synthesis, we could not detect lower 5-HT brain concentrations or decreased 5-HT release. These findings suggest that developmental changes have led to adult 5-HT homeostasis, potentially involving $5-\mathrm{HT}_{1 \mathrm{~A}^{-}}$ autoreceptors. 5- $\mathrm{HT}_{1 \mathrm{~A}}$ receptors can be found somatoden-
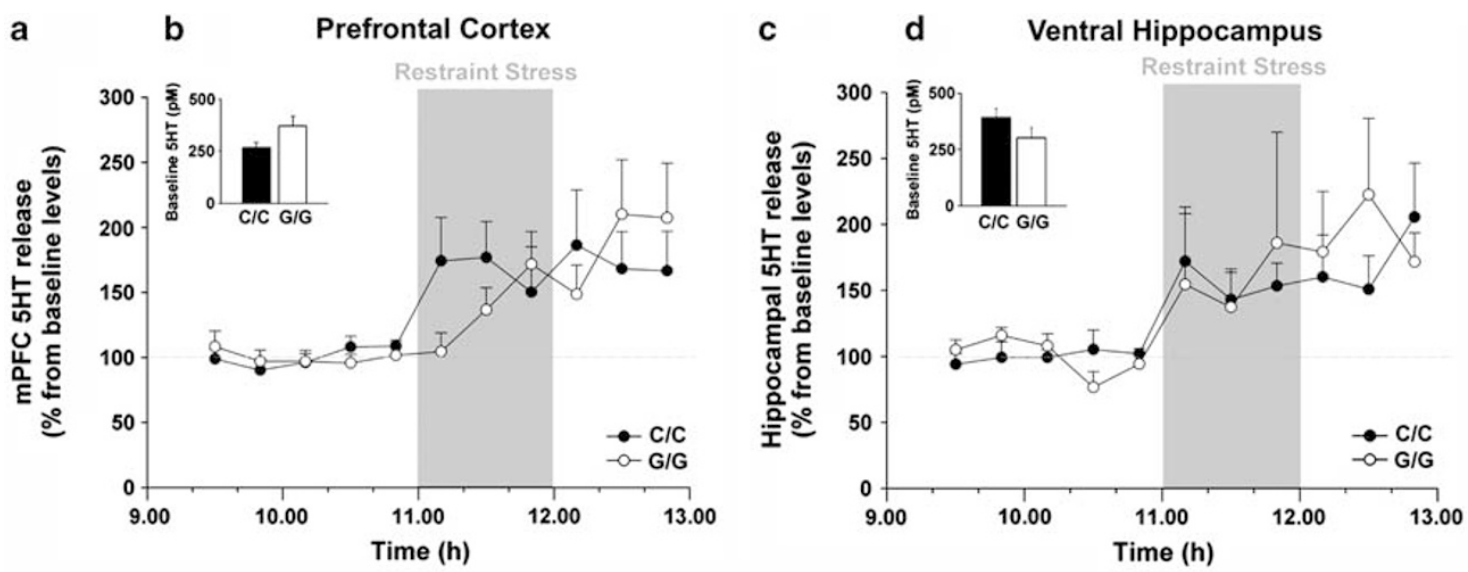

Figure I Basal and stress-induced extracellular 5-HT concentrations in the prefrontal cortex and ventral hippocampus of Tph2 I473G/G and I473C/C mice. (a, c) Percentage increase in 5-HT release in the prefrontal cortex (PFC) (a) and in the ventral hippocampus (c) compared with baseline levels. (b, d) Basal concentration of extracellular 5-HT measured in the PFC (b) and ventral hippocampus (d) of experimentally naive male I473C/C (PFC: $n=8$; ventral hippocampus: $n=5$ ) and I473G/G mice (PFC: $n=9$; ventral hippocampus: $n=6$ ). Dialysates were sampled in 20-min intervals. Pre-stress, basal dialysates were taken over $100 \mathrm{~min}$, samples under acute restraint stress over $60 \mathrm{~min}$ (gray area) and post-stress sampling was conducted for another $60 \mathrm{~min}$ in both I473C/C and I473G/G mice. (b, d) Mean basal 5-HT concentration (averaged from the first five samples collected) in the PFC and ventral hippocampus were not significantly different between I473C/C and I473G/G mice (PFC: $p=0.14$; ventral hippocampus $p=0.12$ ). (a, c) In mice of both Tph2 genotypes, restraint stress increased the release of serotonin in the PFC $\left(F_{\text {Treatment }}(I 0, I 50)=6.60 ; p<0.00 I\right)(a)$ and ventral hippocampus $\left(F_{\text {Treatment }}(I 0,90)=3.25\right.$; $p<0.0013)$ (c). However, no significant difference could be detected between I473C/C and I473G/G mice in the prefrontal cortex ( $F_{G e n o t y p e}$ $(I, 150)=0.004 ; p=0.95)$ and the ventral hippocampus $\left(F_{\text {Genotype }}(I 0,90)=0.25 ; p=0.63\right)$. Furthermore, mice of both genotypes did not react differently to restraint stress (PFC: $F_{\text {Treatment*Genotype }}(10,150)=1.47 ; p=0.155$ and ventral hippocampus $\left.F_{\text {Treatment*Genotype }}(10,90)=0.83 ; p=0.70\right)$. An additional 'area under the curve' analysis for the time points under restraint stress for the PFC also showed no significant differences between I473C/C and I473G/G mice (AUC: $6891.43 \pm 1009.55$ (I473C/C); $5328.45 \pm 526.52(\mid 473 \mathrm{G} / \mathrm{G}))(p=0: 18)$. All data presented are mean values + SEM. Statistical analysis was performed using unpaired $t$-tests and two-way ANOVA of repeated measures. 
a

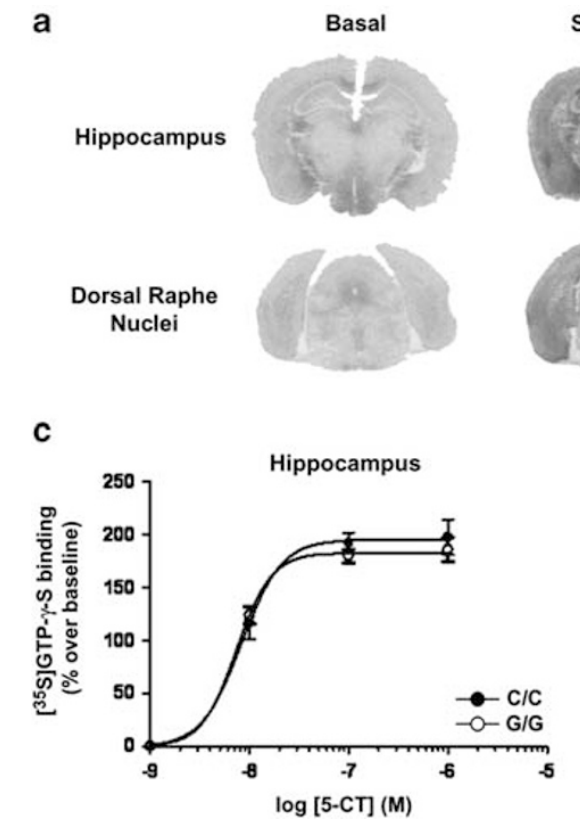

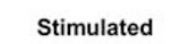
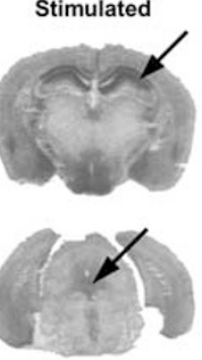

Non Specifc

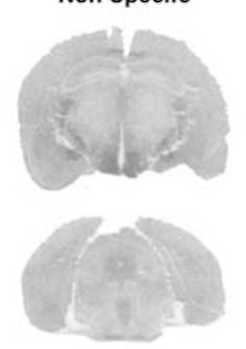

b
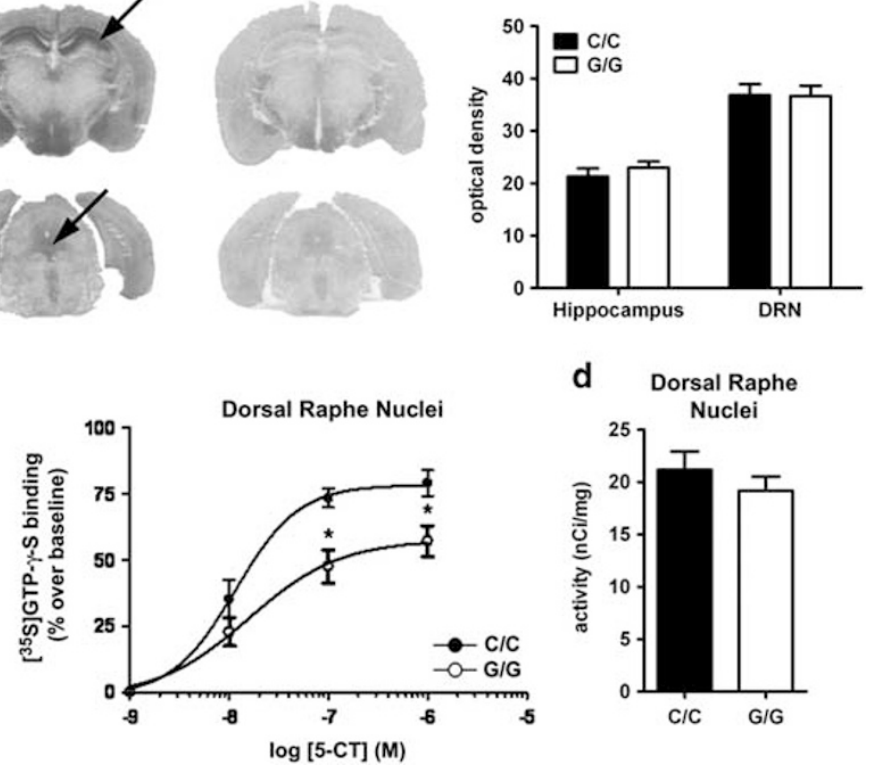

d Dorsal Raphe

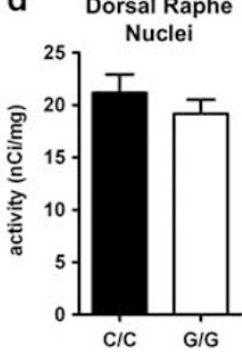

Figure $25-H T_{\text {IA }}$ receptor mediated $\left[{ }^{35} \mathrm{~S}\right] \mathrm{GTP}-\gamma$-S binding $(\mathrm{a}-\mathrm{C})$ and $5-\mathrm{H} \mathrm{T}_{\mathrm{IA}}$ receptor labeling $(\mathrm{d})$ in experimentally naive I473C/C and I473G/G mice. (a) Representative autoradiograms of brain sections from $1473 \mathrm{C} / \mathrm{C}$ mice at the level of the hippocampus and the DRN, labeled by [35S]GTP- $\gamma$-S in the absence (basal) or the presence of $10^{-6} \mathrm{M} 5-\mathrm{CT}$ (stimulated). Nonspecific labeling was obtained from adjacent sections exposed to 5-CT $10^{-6} \mathrm{M}$ plus $10^{-5} \mathrm{M}$ WAY 100635. Arrows indicate investigated brain regions. (b) Basal $\left.{ }^{35} \mathrm{~S}\right] \mathrm{GTP}-\gamma$-S binding is highly similar between mice of both genotypes in the hippocampus and the DRN. (c) In the hippocampus, 5-CT-stimulated $\left[{ }^{35} \mathrm{~S}\right] \mathrm{GTP}-\gamma$-S binding $\left(\mathrm{F}_{\text {Treatment }}(3,32)=148.20\right.$, $p<0.000$; two-way ANOVA of repeated measures) was not significantly different in $1473 \mathrm{G} / \mathrm{G}(n=5)$ and $1473 \mathrm{C} / \mathrm{C}$ mice $(n=5)\left(F_{\text {Genotype }}(1,32)=0.35, p=0.55\right)$. However, the $5-C T$ induced increase in $\left[{ }^{35} \mathrm{~S}\right] \mathrm{GTP}-\gamma-\mathrm{S}$ binding in the DRN ( $\left.\mathrm{F}_{\text {Treatment }}(3,32)=81.35, p<0.000 \mathrm{I}\right)$ was significantly lower in I473G/G mice $(n=5)$ than in I473C/ $\mathrm{C}$ mice $(n=5)\left(F_{\text {Genotype }}(\mathrm{I}, 2 \mathrm{I})=18.73 ; p=0.000 \mathrm{I}\right)$. (d) $5-\mathrm{HT}_{\mathrm{IA}}$ receptor labeling with the selective radioligand $\left[{ }^{3} \mathrm{H}\right] \mathrm{WAY}$ I00635 in the DRN was similar in both $1473 \mathrm{C} / \mathrm{C}(n=10)$ and I473G/G mice $(n=10)$. All data are presented as mean values \pm SEM or as mean values + SEM. Stars represent $p$-values of significances between genotypes obtained from Bonferroni post hoc testing following two-way ANOVA of repeated measures: * $<<0.05$.

dritically as autoreceptors on serotonergic neurons and as heteroreceptors on postsynaptic non-5-HT neurons. In both cases, they are involved in 5-HT regulated inhibition of neuronal firing (Lanfumey and Hamon, 2000). 5-HTinduced $5-\mathrm{HT}_{1 \mathrm{~A}}$ receptor signaling was determined using a $\left[{ }^{35} \mathrm{~S}\right]-\mathrm{GTP}-\gamma-\mathrm{S}$ binding assay. Under basal conditions, that is, in the absence of the non-selective $5-\mathrm{HT}_{1 \mathrm{~A}}$ receptor agonist 5-carboxamido-tryptamine (5-CT), $\left[{ }^{35} \mathrm{~S}\right] \mathrm{GTP}-\gamma$-S labeling within both the DRN and the hippocampus did not differ between 1473G/G and 1473C/C mice (Figures 2a and b). In both groups of mice, 5-CT induced a concentrationdependent increase in $\left[{ }^{35} \mathrm{~S}\right] \mathrm{GTP}-\gamma-\mathrm{S}$ labeling in the DRN and in the hippocampus (Figures $2 \mathrm{a}$ and $\mathrm{c}$ ), which could be prevented by the selective $5-\mathrm{HT}_{1 \mathrm{~A}}$ receptor antagonist WAY $100635(10 \mu \mathrm{M})$ ('nonspecific' condition) (Figure 2a). 5-CTstimulated $\left[{ }^{35} \mathrm{~S}\right] \mathrm{GTP}-\gamma$-S binding in the hippocampus was not significantly different in mice of both $T p h 2$ alleles (Figure 2c). However, the 5-CT-induced increase in $\left[{ }^{35} \mathrm{~S}\right] \mathrm{GTP}-\gamma-\mathrm{S}$ binding within the DRN was significantly lower in $1473 \mathrm{G} / \mathrm{G}$ mice than in $1473 \mathrm{C} / \mathrm{C}$ mice indicating a functional desensitization of 5- $\mathrm{HT}_{1 \mathrm{~A}}$ autoreceptors on 5HT neurons of the DRN (Figure 2c). To explore the possibility that the observed reduction in $\left[{ }^{35} \mathrm{~S}\right]-\mathrm{GTP}-\gamma-\mathrm{S}$ binding in the DRN results from a reduction of 5- $\mathrm{HT}_{1 \mathrm{~A}}$ autoreceptor expression, a receptor binding assay with the specific radioligand $\left[{ }^{3} \mathrm{H}\right]$ WAY 100635 was performed. Quantification of $5-\mathrm{HT}_{1 \mathrm{~A}}$ autoreceptors in DRN showed no difference in radioligand binding between the mice of both Tph2 genotypes (Figure 2d). Taken together, these findings demonstrate that postsynaptic $5-\mathrm{HT}_{1 \mathrm{~A}}$ receptor signaling in $1473 \mathrm{G} / \mathrm{G}$ mice is unchanged and functional desensitization selectively affects $5-\mathrm{HT}_{1 \mathrm{~A}}$ autoreceptors without changing its somatodendritic density on 5-HT neurons.

\section{Anxiety-Related Behavior in Homozygous Tph2 1473G Mice}

Following the biochemical characterization of Tph2 C1473G allele-dependent changes, three cohorts of animals were used to determine SNP-related alterations in general and emotional behavior (Supplementary Table S1).

Baseline parameters like locomotor activity and rearings (Supplementary Figures S1 A-C), body weight (Supplementary Figure S1 D), and nociception (Supplementary Figure S1 E) were similar in $1473 \mathrm{G} / \mathrm{G}$ and $1473 \mathrm{C} / \mathrm{C}$ mice. In mice carrying the Tph2 1473G/G SNP responsible for reduced TPH2 enzymatic efficiency, a significant increase in anxietylike behavior was observed in all four applied paradigms (Figure 3). Three of the tasks are based on a natural approach-avoidance conflict of mice in mazes that consist of sheltered (closed, dark) and unsheltered (open, lit) compartments. Here, an increased avoidance of the unsheltered compartment, which is regarded as an elevation in anxietyrelated behavior, was observed in the elevated plus maze (Figures $3 \mathrm{a}-\mathrm{c}$ ), the light-dark exploration test (Figure $3 \mathrm{~d}-\mathrm{f}$ ) and the elevated zero maze task (Figures $3 \mathrm{i}-\mathrm{j}$ ). The fourth paradigm used was the novelty-induced hypohagia test (Dulawa and Hen, 2005), in which anxiety-related behavior 

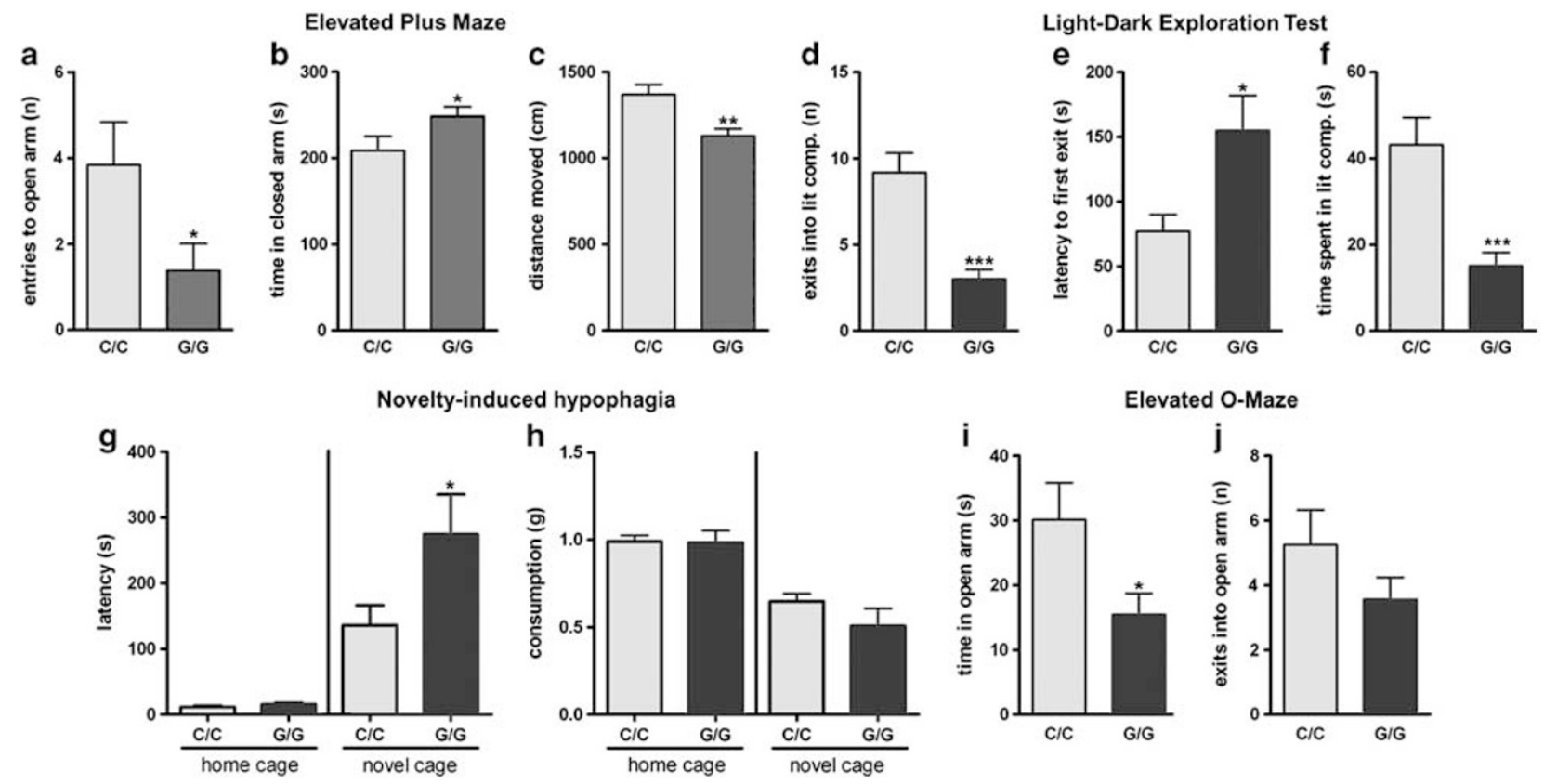

Figure 3 C57BL/6N mice homozygous for the Tph2 I473G allele display increased anxiety-related behavior. I473G/G and I473C/C mice were subjected to behavioral tests assessing anxiety-like behavior (for animal numbers and order of behavioral experiments see Supplementary Table SI). (a-c) Elevated plus maze. 1473G/G mice made significantly fewer entries into the open arms $(p=0.04 \mathrm{I})$ (a) and spent significantly more time in the closed arms of the maze $(p=0.036)(b)$. In addition they displayed a significantly reduced locomotor activity, determined by the distance moved on the maze $(p=0.002)(c)$. ( $d-f)$ Light-dark exploration test. I473G/G mice made significantly fewer entries $(p<0.00 \mathrm{I})$ (d), had a significantly higher latency for their first exit $(p=0.0 \mathrm{l} 6)(\mathrm{e})$, and spent significantly less time in the lit compartment $(p<0.00 \mathrm{I})(f) .(g, h)$ Novelty-induced hypophagia. In the novel cage, mice of both genotypes showed a significantly increased latency to consume milk $\left(\mathrm{F}_{\text {Environment }}(\mathrm{I}, 27)=30.72, p<0.000 \mathrm{I}\right)$ and a highly significant reduction in the amount of consumed milk $\left(F_{\text {Environment }}(I, 27)=48.46, p<0.000 I\right)$. There was a significant effect of genotype on the latency to consume milk $\left(F_{\text {Genotype }}(I, 27)=4.26, p=0.049\right)$. Post hoc analysis revealed a higher latency of $1473 \mathrm{G} / \mathrm{G}$ mice to start consuming sweetened condensed milk in the novel environment $(p<0.05)(\mathrm{g})$. However, the consumption of milk within the 10 min of testing was not different between the two genotypes $\left(F_{\text {Genotype }}(1,27)=0.92, p=0.346\right)$ and not altered by the novel environment $\left(F_{\text {Environment*Genotype }}(I, 27)=1.31, p=0.263\right)(h)$. $(I, j)$ Elevated O-maze. Mice homozygous for the $1473 G$ allele displayed increased anxiety-like behavior, as indicated by a significant decrease in the time spent in the open arms $(p=0.035)$ (i) and a nonsignificant reduction of the number of exits into the open arms $(p=0.194)$ (j). All data presented are mean values + SEM. Stars represent $p$-values obtained by comparing I473G/G and I473C/C mice with either unpaired $t$-test or Bonferroni post-hoc test following two-way ANOVA of repeated measures: $*^{*} p<0.05$; $* * * 0.0$ I; $* * * p<0.00$ I.

of an animal is reflected by its consumatory behavior toward a known, highly palatable food snack in a potentially dangerous, novel environment. Again, 1473G/G mice displayed elevated anxiety-related behavior by showing an increased latency to consume sweetened condensed milk in the novel environment (Figure 3g). However, despite the increased latency to consume milk, the reduction of milk intake in the new environment was not different between mice of both genotypes (Figure $3 \mathrm{~h}$ ).

\section{No Depressive-Like Behavior Under Basal Conditions and After Chronic Mild Stress in Homozygous Tph2 1473G Mice}

Next, we assessed depression-related behaviors in different animal models of depression. Two of these tests, the tail suspension test (Figure 4a) and the forced swimming test (Figure $4 \mathrm{~b}$ ), investigate 'behavioral despair' of an animal by quantifying its escape-oriented behaviors in an inescapable, threatening situation. Differences between genotypes in the immobility time, representing the failure to actively cope with the stressful condition, could not be detected in either test (Figures $4 \mathrm{a}-\mathrm{b}$ ). In the learned helplessness paradigm, the animal's predisposition to develop a helpless behavior after exposure to inescapable electric foot-shocks is assessed. Again, no difference could be observed between mice homozygous for the $1473 \mathrm{G}$ and $1473 \mathrm{C}$ alleles (Figures $4 \mathrm{~d}-\mathrm{f}$ ). Also, mice of both genotype failed to reach criteria for helpless behavior (Chourbaji et al, 2005) (see figure legend for details). Finally, no differences could be found between homozygous $1473 \mathrm{G}$ and 1473C mice when tested for anhedonia in a sucrose preference test (Figure 4c).

In the absence of any basal depressive-like symptoms in $1473 \mathrm{G} / \mathrm{G}$ mice, we assessed whether the $1473 \mathrm{G}$ polymorphism within the C57BL/6N genetic background is associated with an increased vulnerability to chronic stress. Mice were subjected to a chronic mild stress protocol, in which the animals were exposed to three unpredictable mild stressors daily for a total of 6 weeks. During the chronic mild stress procedure, mice of both genotypes reacted to stress with a significant but transient loss of body weight (Supplementary Figure S2 A). Here, the effect of stress was significantly more pronounced in $1473 \mathrm{G} / \mathrm{G}$ animals. One week after termination of stress, mice were tested for locomotor activity as well as for anxiety- and depressive-like behaviors. As a consequence of the chronic mild stress procedure, mice of both genotypes displayed a similar increase in locomotion in the open field test (Supplementary Figure S2 B) and in the elevated plus maze (Supplementary Figure S2 D). A stress-induced increase in immobility was also observed in the tail suspension test and in the forced swimming test, 

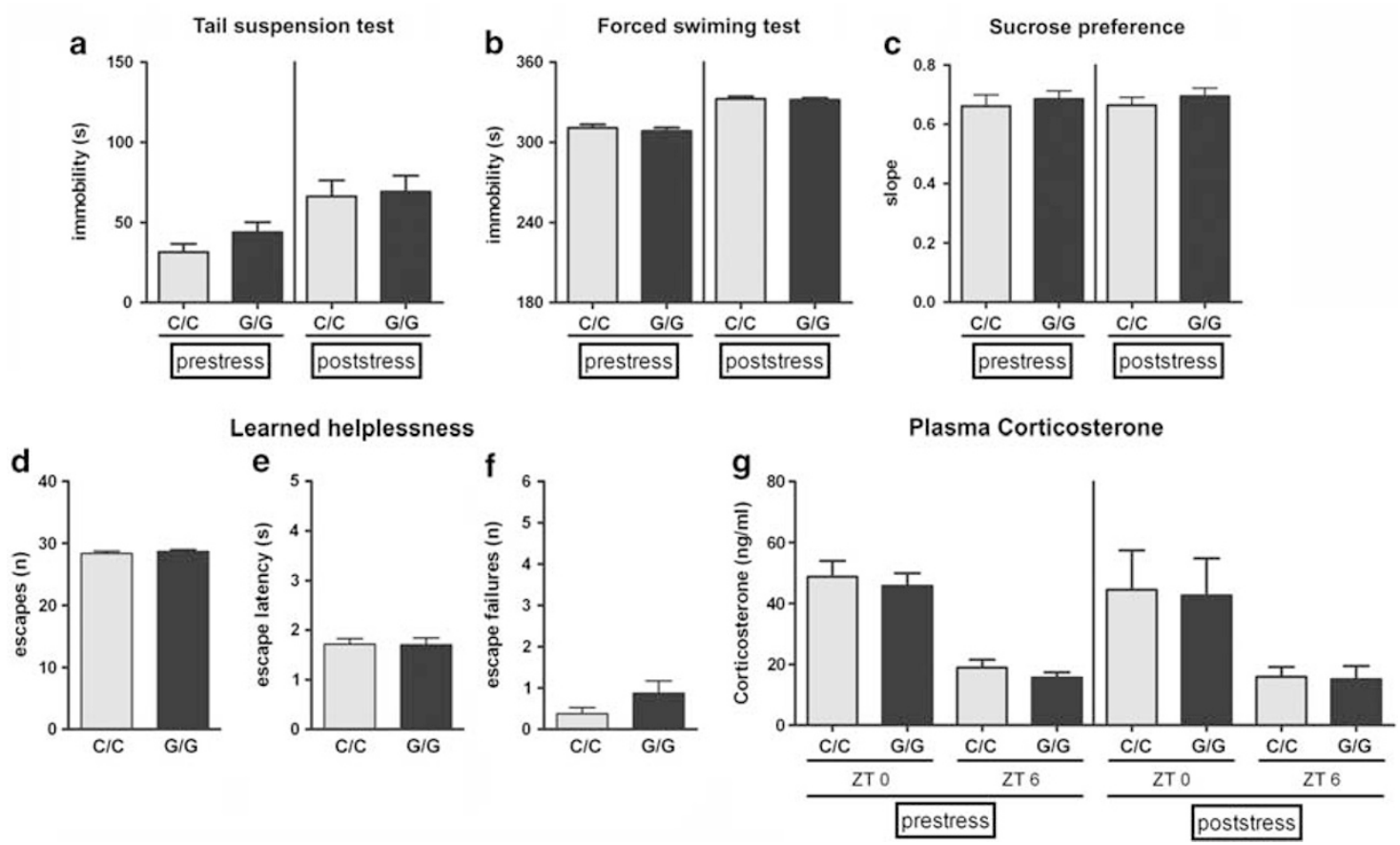

Figure 4 C57BL/6N mice homozygous for the Tph2 I473G allele do not display depressive-like behavior under basal conditions and after chronic mild stress. (a) Tail suspension test (TST) and (b) forced swimming test (FST) (for animal numbers and order of behavioral experiments see Supplementary Table $\mathrm{SI}$ ). In both behavioral paradigms, mice of both Tph2 1473 alleles showed no differences in immobility times, which is a measure of behavioral despair, under unstressed conditions (pre-stress) and following a chronic mild stress procedure (CMS; post-stress) (TST: $F_{\text {Genotype }}(I, 28)=0.68, p=0.4 I 7$; FST: $F_{G e n o t y p e}$ $(1,28)=0.33, p=0.573$; two-way ANOVA of repeated measures). Although immobility times are significantly higher when measured after the CMS procedure $\left(T S T: F_{\text {Stress }}(I, 28)=18.69, p=0.0002\right.$; FST: $\left.F_{\text {Stress }}(I, 28)=237.9, p<0.000 \mathrm{I}\right)$, this is due to the condition of the second testing as a direct comparison with unstressed wild-type C57BL/6N mice revealed lower immobility of stressed mice of both genotypes (Supplementary Figure S2 F+G). (c) Sucrose preference test. Preference to sucrose-containing solutions, determined with a matching law procedure, is undistinguishable in Tph2 I473G/G and $1473 \mathrm{C} / \mathrm{C}$ mice both under pre-stress and post-stress conditions $\left(F_{G e n o t y p e}(1,28)=0.78, p=0.384\right)$. Also, sucrose consumption is not affected by stress $\left(F_{\text {Stress }}(I, 28)=0.04, p=0.844\right) .(d-f)$ Learned helplessness paradigm. I 473G/G mice showed a similar number of escapes $(d)$, escape latencies (e), and escape failures $(f)$ in comparison with $1473 \mathrm{C} / \mathrm{C}$ mice after two sessions of inescapable foot shocks. Mice of both genotypes failed to reach criteria for helpless behavior, which are $>6$ failures out of 30 escape trials and a mean escape latency above $4.75 \mathrm{~s}$ (Chourbaji et al, 2005). (g) Plasma corticosterone concentrations. Venous blood was taken from the animals within the first hour of the dark cycle (peak corticosterone; ZT=0) and 6h later (basal corticosterone; $\mathrm{ZT}=6$ ). Plasma corticosterone concentrations were determined both before (pre-stress) and after (post-stress) mice were subjected to the chronic mild stress procedure. Under both conditions, peak concentrations of corticosterone $(Z T=0)$ are significantly higher in comparison with basal concentrations $(Z T=6)\left(F_{Z T}(I, 28)=32.3 I, p<0.00 I\right.$; three-way ANOVA of repeated measures). However, neither stress no genotype had a significant effect on this rhythmicity $\left(F_{Z T * S t r e s s}(I, 28)=0.04, p=0.836 ; F_{Z T * G e n o t y p e}(I, 28)=0.00 I, p=0.975\right)$. All data presented are mean values $+S E M$. Statistical analysis was performed using unpaired $t$-tests or two- and three-way ANOVA of repeated measures, respectively.

when stressed 1473G/G and 1473C/C mice were compared with a group of unstressed C57Bl/6N mice (Supplementary Figures S2 F and G). However, neither $1473 \mathrm{G} / \mathrm{G}$ nor $1473 \mathrm{C} / \mathrm{C}$ mice showed post-stress depression-related behaviors in all paradigms tested (Figures $4 \mathrm{a}-\mathrm{c}$ ). In addition, peak and basal plasma corticosterone concentrations were unaffected by chronic mild stress in mice of both Tph2 alleles (Figure $4 \mathrm{~g}$ ). Interestingly, the difference in pre-stress anxiety-related behavior between 1473G/G and 1473C/C mice persisted unchanged after stress (Supplementary Figures S2 C-E).

\section{Pharmacological Treatment of Elevated Anxiety with Chronic Escitalopram in Homozygous Tph2 1473G Mice}

Selective serotonin reuptake inhibitors (SSRIs) are the treatment of choice for anxiety disorders (Rickels and Rynn, 2002; Sheehan et al, 1993). The novelty-induced hypophagia test is currently the only behavioral paradigm in mice sensitive to the selective anxiolytic effect of chronic, but not acute, antidepressant treatment (Dulawa and Hen, 2005).
Mice that had been tested in the novelty-induced hypophagia test were treated with $0.225 \mathrm{mg} / \mathrm{ml}$ escitalopram in the drinking water for 6 weeks (for details, see Supplementary Materials and Methods and Supplementary Figure S3), which resulted in an average dosage of $30 \mathrm{mg} / \mathrm{kg} / \mathrm{d}$. In mice of both Tph2 genotypes, escitalopram treatment resulted in a significant decrease in the latency to consume condensed milk (Figure 5a) and a significant reversal of the suppression of milk consumption in the novel environment (Figure 5b). In addition, the SSRI treatment was considerably more effective in the anxious $1473 \mathrm{G} / \mathrm{G}$ mice, as shown by the significantly more pronounced reversal of milk consumption under chronic escitalopram administration (Figure 5b). Also, the treatment effect of escitalopram in reducing the latency for milk consumption in the novel cage was appreciably greater although not statistically significant in $1473 \mathrm{G} / \mathrm{G}$ mice (Figure 5a). More appetite for sweetened condensed milk as the reason for the observed behavior can be excluded, as escitalopram treatment even reduced the total amount of milk intake during home cage training by $13 \%$ in mice of both genotypes (Figure $5 \mathrm{c}$ ). 

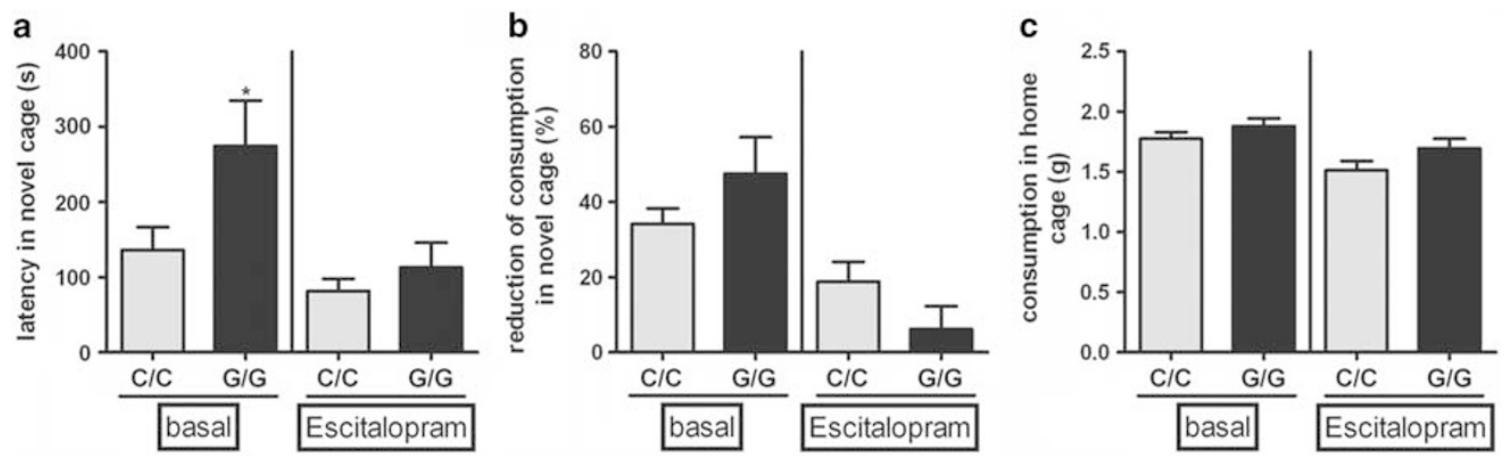

Figure 5 Chronic treatment with escitalopram alleviates anxiety-related behavior in homozygous Tph2 I473G and I473C mice. The novelty-induced hypophagia paradigm was applied in C57BL/6N mice with the $1473 \mathrm{G} / \mathrm{G}$ or $1473 \mathrm{C} / \mathrm{C}$ allele before (basal) and after oral escitalopram treatment (0.225 mg/ml for 6 weeks). The animal numbers and the order of the behavioral experiments are displayed in Supplementary Table SI. (a) Latency to start consuming sweetened condensed milk in the novel cage. Escitalopram significantly reduced latencies $\left(F_{\text {Treatment }}(1,27)=12.44, p=0.0015\right)$ in mice of both genotypes. Also, a trend of significance was observed between $1473 \mathrm{C} / \mathrm{C}$ and I $473 \mathrm{G} / \mathrm{G}$ mice $\left(F_{\text {Genotype }}(1,27)=3.35, p=0.078\right)$. Bonferroni post hoc testing showed that this is due to a significantly higher latency of untreated $1473 \mathrm{G} / \mathrm{G}$ mice compared with $1473 \mathrm{C} / \mathrm{C}$ mice $(* 2<0.05)$, which is no longer present under escitalopram treatment. Furthermore, there was a trend of significance for the effect of escitalopram on latency reduction $\left(F_{\text {Treatment*Genotype }}(I, 27)=3.02\right.$, $p=0.094$ ). (b) Reduction of milk consumption during novel cage testing (for details, see Supplementary Materials and Methods). Escitalopram significantly attenuated the reduction in milk consumption observed in mice of both genotypes in a novel environment $\left(F_{\text {Treatment }}(I, 27)=45.05, p<0.00 \mathrm{I}\right)$. The rescue of milk consumption because of chronic escitalopram treatment was significantly more pronounced in $1473 \mathrm{G} / \mathrm{G}$ mice compared with $1473 \mathrm{C} / \mathrm{C}$ mice $\left(F_{\text {Treatment*Genotype }}(1,27)=9.52, p=0.0047\right)$. However, there was no significant differences detected between mice of both genotypes $\left(F_{G e n o t y p e}\right.$ $(I, 27)=0.002, p=0.963)$. (c) Milk consumption during home cage training. Escitalopram reduced mean milk consumption during home cage training by $13 \%$ on average $\left(F_{\text {Treatment }}(I, 27)=16.23, p<0.00 \mathrm{I}\right)$. The reduction of consumption was similar in mice of both genotypes $\left(F_{\text {Treatment*Genotype }}(I, 27)=0.52\right.$, $p=0.479)$. All data presented are mean values + SEM. Stars represent $p$-values obtained by comparing I473G/G and I473C/C mice with Bonferroni posthoc analysis following two-way ANOVA of repeated measures: $* 0<0.05$.

\section{DISCUSSION}

\section{C1473G Tph2 SNP in Different Inbred Mouse Strains}

The inbred mouse strains $\mathrm{DBA} / 2$ and $\mathrm{BALB} / \mathrm{c}$ (both homozygous for the Tph2 allele 1473G) show increased anxiety-like behavior in comparison with $\mathrm{C} 57 \mathrm{BL} / 6$, which are homozygous for the Tph2 $1473 \mathrm{C}$ allele (Bouwknecht and Paylor, 2002; Griebel et al, 2000; Mozhui et al, 2010). Both $\mathrm{DBA} / 2$ and $\mathrm{BALB} / \mathrm{c}$ strains are regarded as more stresssensitive compared with C57BL/6 because they show higher stress-induced increases in corticosterone concentration and increased anxiety-related behavior following chronic stress (Brinks et al, 2007; Mozhui et al, 2010; Shanks and Anisman, 1988). In addition, 5-HT synthesis, 5-HT tissue concentrations, and extracellular 5-HT levels were shown to be reduced in $\mathrm{DBA} / 2$ and $\mathrm{BALB} / \mathrm{c}$ mice compared with C57Bl6/N (Calcagno et al, 2007; Isles et al, 2005; Jacobsen et al, 2008; Zhang et al, 2004). In our study, the introduction of the 1473G/G SNP into a C57BL/6N genetic background resulted in a defined anxiety-phenotype and reduced 5-HT synthesis rate. These changes occurred despite unaltered tissue and extracellular 5-HT concentrations, and without changes in depressionrelated behavior or in plasma corticosterone concentrations in naive animals or chronically stressed 1473G/G and 1473C/ C C57BL/6N mice. Thus, apart from the anxiety phenotype and the reduced in vivo 5-HT synthesis rate, our findings suggest that genetic variability outside the C1473G Tph2 SNP is responsible for the behavioral and neurochemical differences reported for these different mouse strains.

\section{Mouse Tph2 Polymorphisms in Defined Genetic Backgrounds}

In a previous report (Tenner et al, 2008), the Tph2 $1473 \mathrm{G}$ allele from DBA/2 mice was bred over eight generations to a
C57BL/6J background to obtain congenic mice carrying the same $1473 \mathrm{C} / \mathrm{C}$ or $1473 \mathrm{G} / \mathrm{G}$ alleles as in our study. Using an in vitro $\mathrm{TPH} 2$ activity assay with brain stem lysates, the authors did not show any difference in the TPH2 activity of homozygous $1473 \mathrm{G}$ and $1473 \mathrm{C}$ mice. This finding contradicts other reports that detected a reduction of TPH2 activity with the $1473 \mathrm{G}$ polymorphism (Sakowski et al, 2006; Zhang et al, 2004). In our study, we measured the in vivo 5 -HT synthesis rate in freely behaving animals. For this purpose, we treated live mice with m-hydroxybenzylhydrazine to determine the accumulation of the 5-HT precursor, 5-HTP. Similar to others (Siesser et al, 2010), we found a significant reduction of the in vivo 5-HT synthesis rate in the $1473 \mathrm{G} / \mathrm{G}$ mice. Despite the reduced 5-HT synthesis rate, we could not detect alterations in total 5-HT content and metabolism, which is in accordance with Tenner et al (2008). However, while they argued that these findings reflect the unchanged TPH2 activity in $1473 \mathrm{G} / \mathrm{G}$ mice, here we show that brain region-specific 5-HT concentrations are not reduced despite a significantly decreased in vivo 5 - $\mathrm{HT}$ synthesis rate in $1473 \mathrm{G} / \mathrm{G}$ mice. This is in accordance with a previous report (Siesser et al, 2010). We extend these findings using microdialysis, showing that not only the tissue concentration of 5-HT but also basal extracellular 5$\mathrm{HT}$ and the stress-induced increase in 5-HT release is unaltered in $1473 \mathrm{G} / \mathrm{G}$ mice. At last, Tenner et al (2008) conclude that the Tph2 C1473G SNP is not responsible for behavioral differences between different inbred mouse strains. This assumption is based solely on two behavioral tests in which they could not find any differences in anxietyand depressive-like behavior. In our study, two independent behavioral research teams performed several test batteries to assess depressive- and anxiety-like behavior. We demonstrate that $1473 \mathrm{G} / \mathrm{G}$ mice show a distinct anxiety phenotype, which could be observed in four different anxiety tests. 
A rare human G1463A TPH2 SNP was analyzed via a knock-in approach in transgenic mice (Beaulieu et al, 2008; Jacobsen et al, 2011). Mice homozygous for the corresponding mouse Tph 2 allele $1449 \mathrm{~A}$ showed an $80 \%$ reduction of 5HT synthesis and a strong decrease in total and extracellular 5-HT concentrations. In addition, frontal $5-\mathrm{HT}_{2 \mathrm{~A}}$ receptor function was upregulated and the $5-\mathrm{HT}_{1 \mathrm{~A}}$-receptor agonist-induced hypothermia was blunted (Jacobsen et al, 2011), indicating 5- $\mathrm{HT}_{1 \mathrm{~A}}$ autoreceptor desensitization or downregulation in serotonergic neurons of the raphe nuclei (Gross et al, 2002; Martin et al, 1992). Despite these findings and in contrast to our results, Jacobsen et al (2011) did not find altered $5-\mathrm{HT}_{1 \mathrm{~A}}$ G-protein coupling in the dorsal raphe.

Most relevant to our study are results from their heterozygous 1449A mice, in which 5-HT synthesis was only reduced by $40 \%$ (Beaulieu et al, 2008). This decrease is comparable to the reduction of 5-HT synthesis detected in our $1473 \mathrm{G} / \mathrm{G}$ mice. Identical to our homozygous $1473 \mathrm{G}$ mice, these heterozygous 1449A mice also showed unchanged 5-HT and 5-HIAA tissue concentrations and displayed anxiety-like behavior (Beaulieu et al, 2008). These results suggest that the anxiety phenotype is not directly related to a reduced 5-HT concentration in the adult brain. In contrast to our results, both homozygous and heterozygous 1449A mice show depressive-like behavior (Beaulieu et al, 2008). This finding could be attributed to reduced 5HT neurotransmission in these mice. Although this has been confirmed by microdialysis in homozygous 1449A mice only (Jacobsen et al, 2011), to date it is unclear whether extracellular 5-HT concentration is also decreased in heterozygous $1449 \mathrm{~A}$ mice. The mixed genetic background (F1 generation from matings of $129 \mathrm{~S} 6 / \mathrm{SvEv}$ mice with C57BL/6 mice) used in the study could contribute to the depressive phenotype as well. This was shown for serotonin transporter (5-HTT, Slc6A4) knockout mice, in which depressive behavior was only found when the genetic background was not 100\% C57BL/6 (Kalueff et al, 2010). Together with our findings, this might suggest that additional genetic modifications absent in the C57BL/6 genetic background are necessary for eliciting depressionrelated symptoms in rodents.

In conclusion, we and others (Beaulieu et al, 2008; Siesser et al, 2010) describe two different functional Tph2 SNPs, which are responsible for a reduced 5-HT synthesis rate. Small reductions in 5-HT synthesis during development can likely be compensated for, which suggests that reductions of 5-HT concentration or 5-HT release are not responsible for the anxiogenic behavior in adult mice, but rather adaptive changes that occurred during the animal's development. One of the potential mechanisms during development to regain 5-HT equilibrium would be the identified functional desensitization of $5-\mathrm{HT}_{1 \mathrm{~A}}$ autoreceptors leading to a stabilization of synaptic 5-HT release.

\section{The 5-HT Neuronal System During Development}

Studies that examined key molecules involved in serotonergic neurotransmission during development report interesting parallels. In Tph2 knockout mice, which are almost completely deficient of 5-HT in the central nervous system, a highly significant growth retardation during postnatal development that subsided around P64 could be shown (Alenina et al, 2009). However, we did not observe any overt growth alterations in 1473G/G mice. Recently, changes in emotional behavior accompanied with adaptations in $5-\mathrm{HT}_{1 \mathrm{~A}}$ receptors and corresponding signaling pathways were proposed for Tph2 knockout mice (Waider et al, 2011).

Recent studies investigating $5-\mathrm{HT}_{1 \mathrm{~A}}$ autoreceptors in relation to emotional behaviors revealed interesting similarities to our results. Richardson-Jones et al (2011) show that the reduction of $5-\mathrm{HT}_{1 \mathrm{~A}}$ autoreceptors expression during embryonic development led to an elevation of extracellular 5-HT concentration and to increased anxiety in adult animals, but not to depressive-like behavior. In contrast, downregulation of $5-\mathrm{HT}_{1 \mathrm{~A}}$ autoreceptors in adult mice did not induce similar neurochemical and behavioral changes (Richardson-Jones et al, 2010). In fact, it has been repeatedly shown that the second and third postnatal week is a critical period for the development of brain circuits mediating anxiety in mice. In this period, serotonergic innervations to the hippocampus and cortical areas are formed and perturbances in serotonergic signaling in this period affect anxiety in adulthood (Leonardo and Hen, 2008).

Similarly to $1473 \mathrm{G} / \mathrm{G}$ mice, Slc6a4 knockout mice on a C57BL/6 background displayed elevated anxiety without depression-like alterations (Kalueff et al, 2010) and showed a lower 5-HT synthesis rate in vivo and a desensitization of 5$\mathrm{HT}_{1 \mathrm{~A}}$ autoreceptors (Fabre et al, 2000). However, while in Slc6a4 knockout mice the observed desensitization of 5 $\mathrm{HT}_{1 \mathrm{~A}}$ autoreceptors is due to a reduction of its expression (Fabre et al, 2000), the concentration of 5- $\mathrm{HT}_{1 \mathrm{~A}}$ autoreceptors in the dorsal raphe in our 1473G/G mice is unaltered.

Although we cannot exclude the involvement of other neurotransmitter systems contributing to the observed phenotypes in $1473 \mathrm{G} / \mathrm{G}$ mice, these observations and our data suggest that a potentially adaptive desensitization or downregulation of $5-\mathrm{HT}_{1 \mathrm{~A}}$ autoreceptors during development appears to be a common denominator for an anxiogenic phenotype in mice in which serotonergic neurotransmission has been modulated during development.

\section{Efficient Treatment of Anxiety by Chronic Escitalopram}

An interesting new aspect shown by our study is the virtually selective anxiolytic treatment effect of escitalopram in our anxious $1473 \mathrm{G} / \mathrm{G}$ mice. Chronic exposure to the SSRI escitalopram attenuates the anxiety phenotype in $1473 \mathrm{G} / \mathrm{G}$ mice to levels similar to less anxious $1473 \mathrm{C} / \mathrm{C}$ mice, thus mirroring the selective effect of chronic SSRI treatment in anxiety patients. Recently, increasing evidence has accumulated that the major mechanism of SSRIs in relieving anxiety- and depression-related symptoms is not simply increasing extracellular 5-HT concentrations via reuptake inhibition, but that chronic treatment with drugs like escitalopram, citalopram, or fluoxetine causes a complex modulation of the entire serotonergic neurotransmission, in which the desensitization of $5-\mathrm{HT}_{1 \mathrm{~A}}$ autoreceptors is one of the major changes observed (Blier and de Montigny, 1994; El Mansari et al, 2005; Johnson et al, 2007; Le Poul et al, 2000). In 1473G/G mice, we could identify normal extracellular 5-HT levels and a functional desensitization of $5-\mathrm{HT}_{1 \mathrm{~A}}$ autoreceptors before escitalopram treatment. 
Nonetheless, a strong anxiolytic treatment effect could be observed in our anxious $1473 \mathrm{G} / \mathrm{G}$ mice. Although the exact mechanism of $5-\mathrm{HT}_{1 \mathrm{~A}}$ autoreceptors desensitization in $1473 \mathrm{G} / \mathrm{G}$ mice remains to be elucidated in the future, these mice may be a new tool for in vivo interrogation of SSRIinduced molecular changes that lead to an amelioration of anxiety. These mice could also provide an animal model for preclinical testing of other anxiolytic drugs.

\section{Human TPH2 Polymorphisms}

Human studies have revealed controversial results regarding the association of TPH2 polymorphisms and major depression. Although earlier studies reported significant associations between several TPH2 SNPs and both depression and suicidal behavior (Haghighi et al, 2008; Ke et al, 2006; Lopez de Lara et al, 2007; Van Den Bogaert et al, 2006; Zhou et al, 2005; Zill et al, 2004a,b) more recent studies failed to confirm these findings (De Luca et al, 2006; Lopez et al, 2007; Mann et al, 2008; Zill et al, 2007). Among functionally characterized $\mathrm{TPH} 2$ polymorphisms only a few (including G1463A) result in a clear reduction in enzymatic activity, whereas other polymorphisms have only a minor effect on TPH2 activity (McKinney et al, 2009). This might explain why a clear association with depression was only seen in the case of an extremely rare G1463A TPH2 polymorphism (Zhang et al, 2005) that led to a marked reduction of 5-HT synthesis and 5-HT brain levels in knockin mutant mice with the corresponding G1463A Tph2 SNP (Beaulieu et al, 2008).

In humans, the TPH2 polymorphism -703G/T may be associated with harm avoidance (Gutknecht et al, 2007; Reuter et al, 2007), an 'anxiety' personality trait characterized by excessive anticipatory worry and fear of uncertainty. This 703G/T TPH2 SNP was also shown to be associated with increased reactivity of the amygdala in an emotional face-processing task (Brown et al, 2005; Canli et al, 2005). However, recent studies (Juhasz et al, 2010; Middeldorp et al, 2010) could not confirm a correlation between anxiety symptom scores and several TPH2 polymorphisms but reported on reduced risk-taking behavior in subjects with the most prevalent TPH2 haplotype (Juhasz et al, 2010). In contrast to the conflicting human studies, our homozygous 1473G C57BL/6N mice displayed a defined anxiety phenotype in several conflict-based paradigms and in behavioral tasks investigating anxiety toward novelty. Several reasons may account for these discrepancies, the foremost being species-related, as human anxiety obviously cannot be comprehensively reconstructed in mouse models. Associations of TPH2 polymorphisms with multiple facets of human anxiety, like anxiety personality traits (neuroticism/harm avoidance) or reduced risk-taking behavior may converge in the mouse analysis to a simpler anxiety phenotype.

It should be noted that in human TPH2 SNP studies effects are complicated not only by the heterogeneous genetic background, but also by difficulties in controlling for environmental factors such as stress. In contrast in this study, we used a laboratory C57BL/6N mouse strain housed under controlled conditions, thus the only genetic difference is the C1473G Tph2 polymorphism and other confounding genetic and environmental factors are ex- cluded. Furthermore, many human TPH2 SNPs assessed previously have not been characterized with respect to their functional consequences on TPH2 transcription or 5-HT synthesis rate and consequently 5-HT brain content and 5HT neurotransmission. One interesting finding of our study is that despite a decreased 5-HT synthesis rate we nonetheless encountered a fully compensated $5-\mathrm{HT}$ system with respect to tissue 5-HT content and 5-HT neurotransmission. This apparent picture of a fully functional serotonergic system may disguise compensatory changes as shown here for the 5- $\mathrm{HT}_{1 \mathrm{~A}}$ autoreceptor. The functionally desensitized 5- $\mathrm{HT}_{1 \mathrm{~A}}$ autoreceptor during development might be one reason for the anxiety phenotype observed in our 1473G/G Tph2 SNP mice. In fact, this view is also supported by a study investigating the human $5-\mathrm{HT}_{1 \mathrm{~A}}$ receptor polymorphism $\mathrm{C} 1019 \mathrm{G}$, responsible for an alteration of $5-\mathrm{HT}_{1 \mathrm{~A}}$ autoreceptor concentrations in the DRN (Fakra et al, 2009). In this report, the authors show that the genetic variation, responsible for reduced $5-\mathrm{HT}_{1 \mathrm{~A}}$ receptor availability, is linked with higher amygdala reactivity, which itself is correlated with increased trait anxiety.

\section{CONCLUSION}

On a defined C57Bl6/N genetic background, we have demonstrated that a significant reduction of 5-HT synthesis in mice with a $1473 \mathrm{G} / \mathrm{G}$ polymorphism in the Tph2 gene leads to a functional desensitization of $5-\mathrm{HT}_{1 \mathrm{~A}}$ autoreceptors but does not evoke reductions in basal and stress-induced 5HT release. As these mice do not display depressive-like behavior yet clearly show increased anxiety, developmental compensations, and not acute alterations in serotonergic neurotransmission seem likely to be responsible for the anxiety phenotype. This supports the view of anxiety as a developmental disorder (Leonardo and Hen, 2008). Although we cannot exclude secondary effects of reduced TPH2 activity on other neurotransmitter systems, the anxiolytic effect of the highly selective SSRI escitalopram on the 1473G/ $\mathrm{G}$ mice supports a direct serotonergic effect. Although the exact molecular pathways by which TPH2 activity affects anxiety remains to be elucidated, the functional desensitization of $5-\mathrm{HT}_{1 \mathrm{~A}}$ autoreceptors appears to be promising common denominator for increased anxiety.

\section{ACKNOWLEDGEMENTS}

We thank Caroline Chevarin for her practical help in GTP$\gamma$-S binding studies, Elke Herrmann for animal husbandry, and Cornelius Pawlak and Josef Frank for statistical support. This work has been supported by the following grants: EU HEALTH-F2-2007-201714 DEVANX (to DB and LL), DFG SFB 636 (to DB and PG), Bernstein Center for Computational Neuroscience Heidelberg/Mannheim 01GQ1003B to DB (TPA3) and RS (TPD1).

\section{DISCLOSURE}

The authors declare no conflict of interest. 


\section{REFERENCES}

Alenina N, Kikic D, Todiras M, Mosienko V, Qadri F, Plehm R et al (2009). Growth retardation and altered autonomic control in mice lacking brain serotonin. Proc Natl Acad Sci USA 106: 10332-10337.

Anguelova M, Benkelfat C, Turecki G (2003). A systematic review of association studies investigating genes coding for serotonin receptors and the serotonin transporter: I. Affective disorders. Mol Psychiatry 8: 574-591.

APA (2000). Practice guideline for the treatment of patients with major depressive disorder (revision). American Psychiatric Association. Am J Psychiatry 157(4 Suppl): 1-45.

Azmitia EC, Segal M (1978). An autoradiographic analysis of the differential ascending projections of the dorsal and median raphe nuclei in the rat. $J$ Comparative Neurol 179: 641-667.

Beaulieu JM, Zhang X, Rodriguiz RM, Sotnikova TD, Cools MJ, Wetsel WC et al (2008). Role of GSK3 beta in behavioral abnormalities induced by serotonin deficiency. Proc Natl Acad Sci USA 105: 1333-1338.

Bielohuby M, Herbach N, Wanke R, Maser-Gluth C, Beuschlein F, Wolf $\mathrm{E}$ et al (2007). Growth analysis of the mouse adrenal gland from weaning to adulthood: time- and gender-dependent alterations of cell size and number in the cortical compartment. Am J Physiol 293: E139-E146.

Blier P, de Montigny C (1994). Current advances and trends in the treatment of depression. Trends Pharmacol Sci 15: 220-226.

Blier P, de Montigny C (1999). Serotonin and drug-induced therapeutic responses in major depression, obsessive-compulsive and panic disorders. Neuropsychopharmacology 21(2 Suppl): 91S-98S

Bouwknecht JA, Paylor R (2002). Behavioral and physiological mouse assays for anxiety: a survey in nine mouse strains. Behav Brain Res 136: 489-501.

Brinks V, van der Mark M, de Kloet R, Oitzl M (2007). Emotion and cognition in high and low stress sensitive mouse strains: a combined neuroendocrine and behavioral study in BALB/C and C57BL/6J mice. Frontiers Behav Neurosci 1: 8.

Brown SM, Peet E, Manuck SB, Williamson DE, Dahl RE, Ferrell RE et al (2005). A regulatory variant of the human tryptophan hydroxylase- 2 gene biases amygdala reactivity. Mol Psychiatry 10: $884-888805$

Calcagno E, Canetta A, Guzzetti S, Cervo L, Invernizzi RW (2007). Strain differences in basal and post-citalopram extracellular 5HT in the mouse medial prefrontal cortex and dorsal hippocampus: relation with tryptophan hydroxylase-2 activity. J Neurochem 103: 1111-1120.

Canli T, Congdon E, Gutknecht L, Constable RT, Lesch KP (2005). Amygdala responsiveness is modulated by tryptophan hydroxylase-2 gene variation. J Neural Transm 112: 1479-1485.

Cervo L, Canetta A, Calcagno E, Burbassi S, Sacchetti G, Caccia S et al (2005). Genotype-dependent activity of tryptophan hydroxylase-2 determines the response to citalopram in a mouse model of depression. J Neurosci 25: 8165-8172.

Chourbaji S, Zacher C, Sanchis-Segura C, Dormann C, Vollmayr B, Gass P (2005). Learned helplessness: validity and reliability of depressive-like states in mice. Brain Res 16: 70-78.

Crowley JJ, Blendy JA, Lucki I (2005). Strain-dependent antidepressant-like effects of citalopram in the mouse tail suspension test. Psychopharmacology 183: 257-264.

De Luca V, Hlousek D, Likhodi O, Van Tol HH, Kennedy JL, Wong $\mathrm{AH}$ (2006). The interaction between TPH2 promoter haplotypes and clinical-demographic risk factors in suicide victims with major psychoses. Genes Brain Behav 5: 107-110.

Dulawa SC, Hen R (2005). Recent advances in animal models of chronic antidepressant effects: the novelty-induced hypophagia test. Neurosci Biobehav Rev 29: 771-783.
El Mansari M, Sanchez C, Chouvet G, Renaud B, Haddjeri N (2005). Effects of acute and long-term administration of escitalopram and citalopram on serotonin neurotransmission: an in vivo electrophysiological study in rat brain. Neuropsychopharmacology 30: 1269-1277.

Engblom D, Bilbao A, Sanchis-Segura C, Dahan L, Perreau-Lenz S, Balland B et al (2008). Glutamate receptors on dopamine neurons control the persistence of cocaine seeking. Neuron 59: 497-508.

Fabre V, Beaufour C, Evrard A, Rioux A, Hanoun N, Lesch KP et al (2000). Altered expression and functions of serotonin 5-HT1A and 5-HT1B receptors in knock-out mice lacking the 5-HT transporter. Eur J Neurosci 12: 2299-2310.

Fakra E, Hyde LW, Gorka A, Fisher PM, Munoz KE, Kimak M et al (2009). Effects of HTR1A C(-1019)G on amygdala reactivity and trait anxiety. Arch Gen Psychiatry 66: 33-40.

Froger N, Palazzo E, Boni C, Hanoun N, Saurini F, Joubert C et al (2004). Neurochemical and behavioral alterations in glucocorticoid receptor-impaired transgenic mice after chronic mild stress. J Neurosci 24: 2787-2796.

Fuss J, Ben Abdallah NM, Hensley FW, Weber KJ, Hellweg R, Gass $P$ (2010). Deletion of running-induced hippocampal neurogenesis by irradiation prevents development of an anxious phenotype in mice. PloS One 5: e12769.

Garriock HA, Allen JJ, Delgado P, Nahaz Z, Kling MA, Carpenter L et al (2005). Lack of association of TPH2 exon XI polymorphisms with major depression and treatment resistance. Mol Psychiatry 10: 976-977.

Griebel G, Belzung C, Perrault G, Sanger DJ (2000). Differences in anxiety-related behaviours and in sensitivity to diazepam in inbred and outbred strains of mice. Psychopharmacology 148: 164-170.

Gross C, Zhuang X, Stark K, Ramboz S, Oosting R, Kirby L et al (2002). Serotonin1A receptor acts during development to establish normal anxiety-like behaviour in the adult. Nature 416: 396-400.

Gutknecht L, Jacob C, Strobel A, Kriegebaum C, Muller J, Zeng Y et al (2007). Tryptophan hydroxylase-2 gene variation influences personality traits and disorders related to emotional dysregulation. Int J Neuropsychopharmacol/Offl Scientific J Collegium Internationale Neuropsychopharmacologicum (CINP) 10: 309-320.

Haghighi F, Bach-Mizrachi H, Huang YY, Arango V, Shi S, Dwork AJ et al (2008). Genetic architecture of the human tryptophan hydroxylase 2 gene: existence of neural isoforms and relevance for major depression. Mol Psychiatry 13: 813-820.

Herrnstein RJ (1961). Relative and absolute strength of response as a function of frequency of reinforcement. J Exp Anal Behav 4: 267-272.

Hoff J (2000). Methods of blood collection in the mouse. Lab Animal 29: 47-53.

Isles AR, Hathway GJ, Humby T, de la Riva C, Kendrick KM, Wilkinson LS (2005). An mTph2 SNP gives rise to alterations in extracellular 5-HT levels, but not in performance on a delayedreinforcement task. Eur J Neurosci 22: 997-1000.

Jacobsen JP, Nielsen EO, Hummel R, Redrobe JP, Mirza N, Weikop $P$ (2008). Insensitivity of NMRI mice to selective serotonin reuptake inhibitors in the tail suspension test can be reversed by co-treatment with 5-hydroxytryptophan. Psychopharmacology 199: $137-150$.

Jacobsen JP, Siesser WB, Sachs BD, Peterson S, Cools MJ, Setola V et al (2011). Deficient serotonin neurotransmission and depression-like serotonin biomarker alterations in tryptophan hydroxylase 2 (Tph2) loss-of-function mice. Mol Psychiatry; e-pub ahead of print 3 May 2011.

Johnson DA, Grant EJ, Ingram CD, Gartside SE (2007). Glucocorticoid receptor antagonists hasten and augment neurochemical responses to a selective serotonin reuptake inhibitor antidepressant. Biol Psychiatry 62: 1228-1235.

Juhasz G, Downey D, Hinvest N, Thomas E, Chase D, Toth ZG et al (2010). Risk-taking behavior in a gambling task associated with 
variations in the tryptophan hydroxylase 2 gene: relevance to psychiatric disorders. Neuropsychopharmacology 35: 1109-1119.

Kalueff AV, Olivier JD, Nonkes LJ, Homberg JR (2010). Conserved role for the serotonin transporter gene in rat and mouse neurobehavioral endophenotypes. Neurosci Biobehav Rev 34: 373-386.

Ke L, Qi ZY, Ping Y, Ren CY (2006). Effect of SNP at position 40237 in exon 7 of the TPH2 gene on susceptibility to suicide. Brain Res 1122: 24-26.

Khawaja X (1995). Quantitative autoradiographic characterisation of the binding of [3H]WAY-100635, a selective 5-HT1A receptor antagonist. Brain Res 673: 217-225.

Lanfumey L, Hamon M (2000). Central 5-HT(1A) receptors: regional distribution and functional characteristics. Nucl Med Biol 27: 429-435.

Le Poul E, Boni C, Hanoun N, Laporte AM, Laaris N, Chauveau J et al (2000). Differential adaptation of brain 5-HT1A and 5HT1B receptors and 5-HT transporter in rats treated chronically with fluoxetine. Neuropharmacology 39: 110-122.

Leonardo ED, Hen R (2008). Anxiety as a developmental disorder. Neuropsychopharmacology 33: 134-140.

Lopez de Lara C, Brezo J, Rouleau G, Lesage A, Dumont M, Alda M et al (2007). Effect of tryptophan hydroxylase-2 gene variants on suicide risk in major depression. Biol Psychiatry 62: 72-80.

Lopez VA, Detera-Wadleigh S, Cardona I, Kassem L, McMahon FJ (2007). Nested association between genetic variation in tryptophan hydroxylase II, bipolar affective disorder, and suicide attempts. Biol Psychiatry 61: 181-186.

Mann JJ, Currier D, Murphy L, Huang YY, Galfalvy H, Brent D et al (2008). No association between a TPH2 promoter polymorphism and mood disorders or monoamine turnover. J Affect Disord 106: $117-121$.

Martin KF, Phillips I, Hearson M, Prow MR, Heal DJ (1992). Characterization of 8-OH-DPAT-induced hypothermia in mice as a 5-HT1A autoreceptor response and its evaluation as a model to selectively identify antidepressants. Br J Pharmacol 107: 15-21.

McKinney JA, Turel B, Winge I, Knappskog PM, Haavik J (2009). Functional properties of missense variants of human tryptophan hydroxylase 2. Human Mutation 30: 787-794.

Middeldorp CM, Slof-Op 't Landt MC, Medland SE, van Beijsterveldt CE, Bartels M, Willemsen G et al (2010). Anxiety and depression in children and adults: influence of serotonergic and neurotrophic genes? Genes Brain Behav 9: 808-816.

Mozhui K, Karlsson RM, Kash TL, Ihne J, Norcross M, Patel S et al (2010). Strain differences in stress responsivity are associated with divergent amygdala gene expression and glutamatemediated neuronal excitability. J Neurosci 30: 5357-5367.

Murphy DL, Lesch KP (2008). Targeting the murine serotonin transporter: insights into human neurobiology. Nat Rev Neurosci 9: 85-96.

Pothion S, Bizot JC, Trovero F, Belzung C (2004). Strain differences in sucrose preference and in the consequences of unpredictable chronic mild stress. Behav Brain Res 155: 135-146.

Ressler KJ, Nemeroff CB (2000). Role of serotonergic and noradrenergic systems in the pathophysiology of depression and anxiety disorders. Depress Anxiety 12(Suppl 1): 2-19.

Reuter M, Kuepper Y, Hennig J (2007). Association between a polymorphism in the promoter region of the TPH2 gene and the personality trait of harm avoidance. Int J Neuropsychopharmacol/Off Scientific J Collegium Internationale Neuropsychopharmacologicum (CINP) 10: 401-404.

Richardson-Jones JW, Craige CP, Guiard BP, Stephen A, Metzger KL, Kung HF et al (2010). 5-HT1A autoreceptor levels determine vulnerability to stress and response to antidepressants. Neuron 65: $40-52$.

Richardson-Jones JW, Craige CP, Nguyen TH, Kung HF, Gardier AM, Dranovsky A et al (2011). Serotonin-1A autoreceptors are necessary and sufficient for the normal formation of circuits underlying innate anxiety. J Neurosci 31: 6008-6018.

Rickels K, Rynn M (2002). Pharmacotherapy of generalized anxiety disorder. J Clin Psychiatry 63(Suppl 14): 9-16.

Sakowski SA, Geddes TJ, Kuhn DM (2006). Mouse tryptophan hydroxylase isoform 2 and the role of proline 447 in enzyme function. $J$ Neurochem 96: 758-765.

Sanchis-Segura C, Cline BH, Marsicano G, Lutz B, Spanagel R (2004). Reduced sensitivity to reward in CB1 knockout mice. Psychopharmacology 176: 223-232.

Shanks N, Anisman H (1988). Stressor-provoked behavioral changes in six strains of mice. Behav Neurosci 102: 894-905.

Sheehan DV, Raj BA, Trehan RR, Knapp EL (1993). Serotonin in panic disorder and social phobia. Int Clin Psychopharmacol 8(Suppl 2): 63-77.

Siesser WB, Zhang X, Jacobsen JP, Sotnikova TD, Gainetdinov RR, Caron MG (2010). Tryptophan hydroxylase 2 genotype determines brain serotonin synthesis but not tissue content in $\mathrm{C} 57 \mathrm{Bl} /$ 6 and BALB/c congenic mice. Neurosci Lett 481: 6-11.

Tenner K, Qadri F, Bert B, Voigt JP, Bader M (2008). The mTPH2 C1473G single nucleotide polymorphism is not responsible for behavioural differences between mouse strains. Neurosci Lett 431: 21-25.

Van Den Bogaert A, Sleegers K, De Zutter S, Heyrman L, Norrback $\mathrm{KF}$, Adolfsson $\mathrm{R}$ et al (2006). Association of brain-specific tryptophan hydroxylase, TPH2, with unipolar and bipolar disorder in a Northern Swedish, isolated population. Arch Gen Psychiatry 63: 1103-1110.

Waider J, Araragi N, Gutknecht L, Lesch KP (2011). Tryptophan hydroxylase-2 (TPH2) in disorders of cognitive control and emotion regulation: a perspective. Psychoneuroendocrinology 36: 393-405.

Walther DJ, Peter JU, Bashammakh S, Hortnagl H, Voits M, Fink H et al (2003). Synthesis of serotonin by a second tryptophan hydroxylase isoform. Science (New York, NY) 299: 76.

Willner P (1997). Validity, reliability and utility of the chronic mild stress model of depression: a 10-year review and evaluation. Psychopharmacology 134: 319-329.

Yu YW, Tsai SJ, Hong CJ, Chen TJ, Chen MC, Yang CW (2005). Association study of a monoamine oxidase a gene promoter polymorphism with major depressive disorder and antidepressant response. Neuropsychopharmacology 30: 1719-1723.

Zhang X, Beaulieu JM, Sotnikova TD, Gainetdinov RR, Caron MG (2004). Tryptophan hydroxylase-2 controls brain serotonin synthesis. Science (New York, NY) 305: 217.

Zhang X, Gainetdinov RR, Beaulieu JM, Sotnikova TD, Burch LH, Williams RB et al (2005). Loss-of-function mutation in tryptophan hydroxylase-2 identified in unipolar major depression. Neuron 45: 11-16.

Zhou Z, Roy A, Lipsky R, Kuchipudi K, Zhu G, Taubman J et al (2005). Haplotype-based linkage of tryptophan hydroxylase 2 to suicide attempt, major depression, and cerebrospinal fluid 5hydroxyindoleacetic acid in 4 populations. Arch Gen Psychiatry 62: 1109-1118.

Zill P, Baghai TC, Zwanzger P, Schule C, Eser D, Rupprecht R et al (2004a). SNP and haplotype analysis of a novel tryptophan hydroxylase isoform (TPH2) gene provide evidence for association with major depression. Mol Psychiatry 9: 1030-1036.

Zill P, Buttner A, Eisenmenger W, Moller HJ, Bondy B, Ackenheil M (2004b). Single nucleotide polymorphism and haplotype analysis of a novel tryptophan hydroxylase isoform (TPH2) gene in suicide victims. Biol Psychiatry 56: 581-586.

Zill P, Preuss UW, Koller G, Bondy B, Soyka M (2007). SNP- and haplotype analysis of the tryptophan hydroxylase 2 gene in alcohol-dependent patients and alcohol-related suicide. Neuropsychopharmacology 32: 1687-1694.

Supplementary Information accompanies the paper on the Neuropsychopharmacology website (http://www.nature.com/npp) 